\title{
SODIUM FLUORIDE-INDUCED OXIDATIVE STRESS AND HISTOLOGICAL CHANGES IN LIVER OF SWISS ALBINO MICE AND AMELIORATION BY OCIMUM SANCTUM LINN.
}

\author{
BHAGWENDRA PRAKASH, SURESH KUMAR SABAL, RAJBALA VERMA, JOHN PJ, INDERPAL SONI*
}

Department of Zoology, Environmental Toxicology Laboratory, Centre for Advanced Studies, University of Rajasthan, Jaipur, Rajasthan, India. Email: inderpalsoni@gmail.com; prakashbhagwendra@gmail.com

Received: 20 April 2018, Revised and Accepted: 19 May 2018

\section{ABSTRACT}

Objective: The present study was designed to evaluate hepatotoxicity induced by sodium fluoride (NaF) in Swiss albino mice and amelioration by Ocimum sanctum Linn.

Methods: Mice were divided into six groups, Group I received tap water, Group II received low dose of NaF (8 mg/L), Group III high dose of NaF $(80 \mathrm{mg} / \mathrm{L})$ in drinking water, Group IV tap water along with $250 \mathrm{mg} / \mathrm{kg}$ body weight/day leaf extract of 0 . sanctum Linn., Group V $8 \mathrm{mg} / \mathrm{L}$ NaF in drinking water and $250 \mathrm{mg} / \mathrm{kg}$ body weight leaf extract of 0 . sanctum Linn., and Group VI $80 \mathrm{mg} / \mathrm{L} \mathrm{NaF}$ in drinking water along with leaf extract of O. sanctum Linn. $250 \mathrm{mg} / \mathrm{kg}$ body weight/day for 90 days. On the $91^{\text {st }}$ day, the animals were autopsied and liver tissue samples were taken to assess histopathological changes and oxidative stress by estimating glutathione peroxidase, superoxide dismutase, and catalase.

Results: A highly significant decrease in the activity of antioxidant enzymes occurred with the high dose (Group III). Hepatic histopathological architecture exhibited deformities, namely, ballooning, hypertrophy, hepatocellular necrosis, infiltration of mononuclear cells, deformed central vein, sinusoidal dilation, and binucleated cells. Low-dose group (Group II) showed a significant decrease in antioxidant enzyme levels as compared to control group, and histological sections of liver showed dilated sinusoids, infiltration of mononuclear cells, ballooning, and hypertrophy of hepatocytes. Groups IV and V showed no pathological features. Group VI showed less damage to the liver as compared to Group III.

Conclusion: The results revealed that the administration of leaf extract of 0 . sanctum Linn. elicited protection against NaF-induced hepatotoxicity and oxidative stress. It may, therefore, be inferred that fluoride caused hepatotoxicity in Swiss albino mice at the tested dose levels can be ameliorated by O. sanctum Linn.

Keywords: Fluoride, Mice, Drinking water, Hepatotoxicity, Amelioration, Ocimum sanctum Linn.

(c) 2018 The Authors. Published by Innovare Academic Sciences Pvt Ltd. This is an open access article under the CC BY license (http://creativecommons. org/licenses/by/4. 0/) DOI: http://dx.doi.org/10.22159/ajpcr.2018.v11i9.26840

\section{INTRODUCTION}

Fluoride is found everywhere in the ecosystem. It is an important toxicant which results from both natural and anthropogenic activities. Fluoride $\left(\mathrm{F}^{-}\right)$anion is the reduced form of fluorine which is widely distributed all over the world. Human beings and animals are exposed to fluoride directly or indirectly almost every day. The main source of human exposure to fluoride is through drinking water. They consume water derived from both surface and groundwater reservoirs, and their intake of naturally occurring fluoride varies with the geology of the particular region from which they obtain drinking water. The amount of fluoride in ground water ranges from $<0.1 \mathrm{mg} / \mathrm{L}$ to more than $25 \mathrm{mg} / \mathrm{L}$, while in surface waters, it ranges from 0.01 to $0.3 \mathrm{mg} / \mathrm{L}$ [1]. Fluoride is also present in a variety of dental care products such as dentifrices, topical gels, and restorative gels [2]. Fluoride has both positive and negative effects on living organisms. The effect depends on the concentration of fluoride; lower concentration plays a positive role, thereby protecting our bones and teeth from decaying. On the other hand, excess amounts lead to health problems. Therapeutic doses of fluoride used during the treatment of otosclerosis and osteoporosis can also cause fluoride toxicity [3]. Exposure to higher than permissible levels of fluoride, i.e., $>1.5 \mathrm{mg} / \mathrm{L}$ may lead to serious health problems [4]. Acute fluoride toxicity is known to cause nausea, salivation, and abdominal pain. Skeletal and dental fluorosis, arthritic pain, premature aging, and crippling fluorosis are associated with chronic fluoride toxicity. Chronic exposure of fluoride is also associated with impairment in cognition, autoimmunity, and memory. Renal toxicity, metabolic disorder, muscular atrophy, decalcification, and fragility of bones are also the result of fluoride intoxication [5].

The liver is the active site of metabolism and prone to fluoride intoxication. Too high amount of fluoride may disturb liver functioning and homeostasis [6] and produce abnormalities such as degenerative and inflammatory changes [7]. The high amount of fluoride exposure is known to trigger hepatic cellular hyperplasia and dilatation of sinusoids [8]. Several types of metabolic enzyme changes and histopathological changes have been reported in calves, sheep, and rats by several researchers [9-11]. Ocimum sanctum Linn. (Tulsi) is a small herb, native to tropical and subtropical regions and possesses medicinal properties such as anti-ulcer, analgesic, antioxidant, hepatoprotective, neuroprotective, anti-inflammatory, anti-arthritic, immunomodulatory, anticancer, anti-asthmatic, gastroprotective, and anti-diabetic activities [12-19]. The present study was designed to investigate the effects of sodium fluoride $(\mathrm{NaF})$ on antioxidative enzymes and hepatic histological architecture in adult mice and its amelioration by 0 . sanctum Linn.

\section{METHODS}

\section{Animals handling and care}

Healthy male Swiss albino mice (8 weeks old and weighing 25-30 g) were kept in cages with sawdust for bedding and maintained under standard laboratory conditions (temperature of $23 \pm 3^{\circ} \mathrm{C}, 40-70 \%$ humidity, and $12 \mathrm{~h}: 12 \mathrm{~h}$ dark:light cycle). The animals were maintained on standard rodent pellets and drinking water ad libitum throughout 
the study. The ethical clearance for the use of animals in the study was obtained from the Institutional Animal Ethical Committee. Recommendations of the committee for the purpose of the control and supervision of experimental animals, India, were followed during the entire course of experiments.

\section{Chemical}

NaF (NaF, CAS No. 7681-49-4, >99\%) purchased from Merck, India, was dissolved in drinking water.

\section{Plant material and extraction}

O. sanctum Linn. was grown on the premises of Department of Zoology, University of Rajasthan, Jaipur, and authenticated and a voucher sample deposited in the Herbarium, Department of Botany, University of Rajasthan, Jaipur. Dried leaf powder was subjected to the extraction with $70 \%$ ethanol in a Soxhlet apparatus. The obtained extract was concentrated by evaporation process and semisolid extract obtained was then dissolved in distilled water.

\section{Treatment}

The male Swiss albino mice were randomly divided into six groups as follows:

- Group I ( $\mathrm{n}=8)$ : Animals received tap water for 90 days and served as control.

- Group II (n=8): Animals received daily $8 \mathrm{mg} / \mathrm{L} \mathrm{NaF}$ through drinking water served as low-dose group.

- Group III ( $\mathrm{n}=8$ ): Animals treated daily with $80 \mathrm{mg} / \mathrm{L} \mathrm{NaF}$ through drinking water served as high-dose group.

- Group IV (n=8): Animals received tap water and treated daily with $250 \mathrm{mg} / \mathrm{kg}$ body weight of 0 . sanctum Linn. leaf extract in distilled water through oral gavage for 90 days.

- Group V (n=8): Animals received $8 \mathrm{mg} / \mathrm{L} \mathrm{NaF}$ in drinking water and treated daily with $250 \mathrm{mg} / \mathrm{kg}$ body weight of 0 . sanctum Linn. leaf extract in distilled water through oral gavage for 90 days.

- Group VI ( $\mathrm{n}=8)$ : Animals received $80 \mathrm{mg} / \mathrm{L} \mathrm{NaF}$ in drinking water and treated daily with $250 \mathrm{mg} / \mathrm{kg}$ body weight of $O$. sanctum Linn. leaf extract in distilled water through oral gavage for 90 days.

The consumption of drinking water, food intake, and body weight gain was recorded every week throughout the study.

\section{Biochemical assay}

Fresh liver tissue was homogenized in phosphate buffer at $\mathrm{pH}$ 7.4. The homogenate was used to estimate the levels of glutathione peroxidase (GPx), catalase (CAT), superoxide dismutase (SOD), and protein.

CAT activity was measured by the method given by Aebi [20]. It was estimated from the change in absorbance at $240 \mathrm{~nm}$ by spectrophotometer. SOD activity was assayed according to the method given by Marklund and Marklund [21]. It was estimated from the change in absorbance at $420 \mathrm{~nm}$ by spectrophotometer. The specific activities of CAT and SOD were expressed in terms of $\mu \mathrm{M} / \mathrm{mg}$ protein. GPx was measured by the method given by Paglia and Valentine [22] and activity expressed in terms of nmol NADPH consumed/min/ mg protein. The activity of GPx was calculated from the change in absorbance at $340 \mathrm{~nm}$. Protein content of each sample homogenate was determined by the method of Lowry et al. [23]. Protein was estimated from the change in absorbance at $640 \mathrm{~nm}$ using bovine serum albumin as standard.

\section{Statistical analysis}

Data are expressed as mean \pm standard error of the mean and subjected to one-way ANOVA followed by Tukey's honestly significant difference test. The $\mathrm{p}<0.05$ level was set as significant and $\mathrm{p}<0.01$ level was set as highly significant.

\section{Histopathology}

Bouin's fluid was used as a fixative to fix portions of liver tissue, dehydrated through ordered alcoholic series, and embedded in paraffin wax. Routine microtomy was carried out to obtain $5 \mu \mathrm{m}$-thick tissue sections. Hematoxylin-Eosin technique was used to stain sections which were then viewed under light microscope.

\section{RESULTS}

Organ somatic index (OSI) of the liver

Body weight and liver weight of all the animals on autopsy day were recorded, and OSI of control and treated groups was calculated using the following formula:

$$
\text { OSI }=\frac{\text { Weight of theliver }}{\text { Totalbodyweight }}
$$

As shown in Fig. 1, the ratio of body and liver weights of the mice treated with $\mathrm{NaF}$ (Groups II and III) decreased as compared to the Group I (controls). Mice administered with $O$. sanctum Linn. alone (Group IV) or with $\mathrm{NaF}$ and $O$. sanctum Linn. (Groups $\mathrm{V}$ and $\mathrm{VI}$ ) showed an increase in the ratio of body and liver weight as compared to Groups II and III respectively.

\section{Biochemical analysis in the liver}

This study was conducted for 90 days to observe $\mathrm{NaF}$-induced hepatotoxicity and its mitigation by ethanolic leaf extract of $O$. sanctum Linn. in Swiss albino mice. Mice that received a high dose of NaF showed highly significant decrease $(\mathrm{p}<0.01)$ in the activity of CAT (Fig. 2a), SOD (Fig. 2b), and GPx enzymes (Fig. 2c) as compared to Control group. The low-dose group (Group II) showed significant $(p<0.05)$ decrease in SOD, CAT activity, and highly significant decrease in GPx enzyme activity as compared to control group. The group that received leaf extract alone (Group IV) was comparable with control (Group I). The ameliorative study showed a significant increase in antioxidant enzymes activity (Fig. 2a-c). CAT, GPx, and SOD activities were significantly high $(\mathrm{p}<0.05)$ in Groups $\mathrm{V}$ and $\mathrm{VI}$, respectively, when compared with fluoride administered mice (Groups II and III). Exposure to $O$. sanctum Linn. ( $250 \mathrm{mg} / \mathrm{kg}$ body weight) alone induced a non-significant augmentation in CAT, SOD, and GPx levels, as compared to control animals.

In ameliorative study, Groups V and VI received $O$. sanctum Linn. along with NaF. Group V showed a significant increase in CAT, GPx activity, and non-significant increase SOD activity as compared to Group II which treated with the low dose of NaF. Group VI also showed significant enhancement in the level of SOD, CAT, and GPx as compared to Group III.

\section{Histopathology}

Hepatic histopathological alterations following exposure to fluoride are shown in Figs. 3 and 4, and the severity of lesions is summarized in Table 1. The mice of Group II treated with $8 \mathrm{mg}$ $\mathrm{NaF} / \mathrm{L}$ exhibited the regular hepatic lobular pattern. However, hypertrophy of Kupffer cells, hepatocellular degeneration, cell infiltration, and sinusoid dilatations were also observed (Figs. 3b and $4 \mathrm{a}, \mathrm{b}$ and $\mathrm{f}$ ). Vacuolization, binucleated cells, and ballooned hepatocytes were found scattered in certain areas. In animals of Group III treated with $80 \mathrm{mg}$ of $\mathrm{NaF} / \mathrm{L}$, the normal lobular pattern of hepatic cords was distorted. In certain areas, necrosis, binucleated hepatocytes, and ballooned hepatocytes were observed (Figs. 3c and $4 \mathrm{c}$-e). Hypertrophy and hyperplasia along with cell infiltration were observed in mice. Hepatocellular adenoma and carcinoma were indicated by the presence of binucleated hepatic cells (Fig. 3b). Central vein boundary showed distorted cells, thereby indicating centrilobular necrosis. High dose of fluoride-induced cell infiltration near the portal triad and between hepatocytes (Fig. 4a).

Liver histology of Groups I and IV showed normal hepatic parenchyma, hepatic lobules, and hepatocytes organized in cords radiating from the central canal (Fig. 3a and d). Leaf extract of 0 . sanctum Linn. is known to possess therapeutic potential due to the presence of secondary metabolites, namely, eugenol and urosolic acid. These secondary metabolites and phenolic compounds possess the potential to scavenge free radicals from cells and prevent damage. Groups V and VI treated 
with 0 . sanctum Linn. showed hepatoprotective features compared to Groups II and III (Table 1).

The obtained results thus indicate that fluoride has the potential to induce toxicity, but it can be mitigated through the administration of leaf extract of $O$. sanctum Linn.

\section{DISCUSSION}

Fluoride is recognized as an environmental pollutant and a major threat to human health on chronic exposure. Globally, humans are affected with this major problem of fluoride-containing drinking water. Fluoride is a toxic agent that can permeate cell membrane and disturb homeostasis of cell. In the present study, the ethanolic extract of $O$. sanctum Linn. leaves was used to evaluate the hepatoprotective activity against toxicity induced by $\mathrm{NaF}$ in Swiss albino mice.

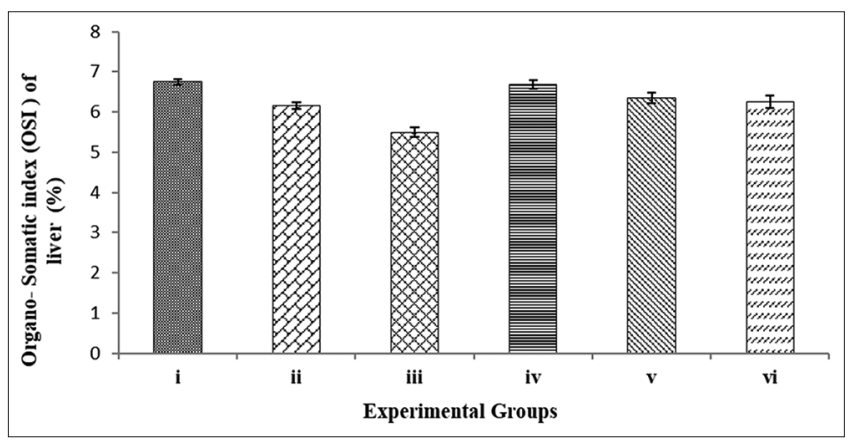

Fig. 1: Relationship between organ-somatic index and treatment of sodium fluoride and Ocimum sanctum Linn

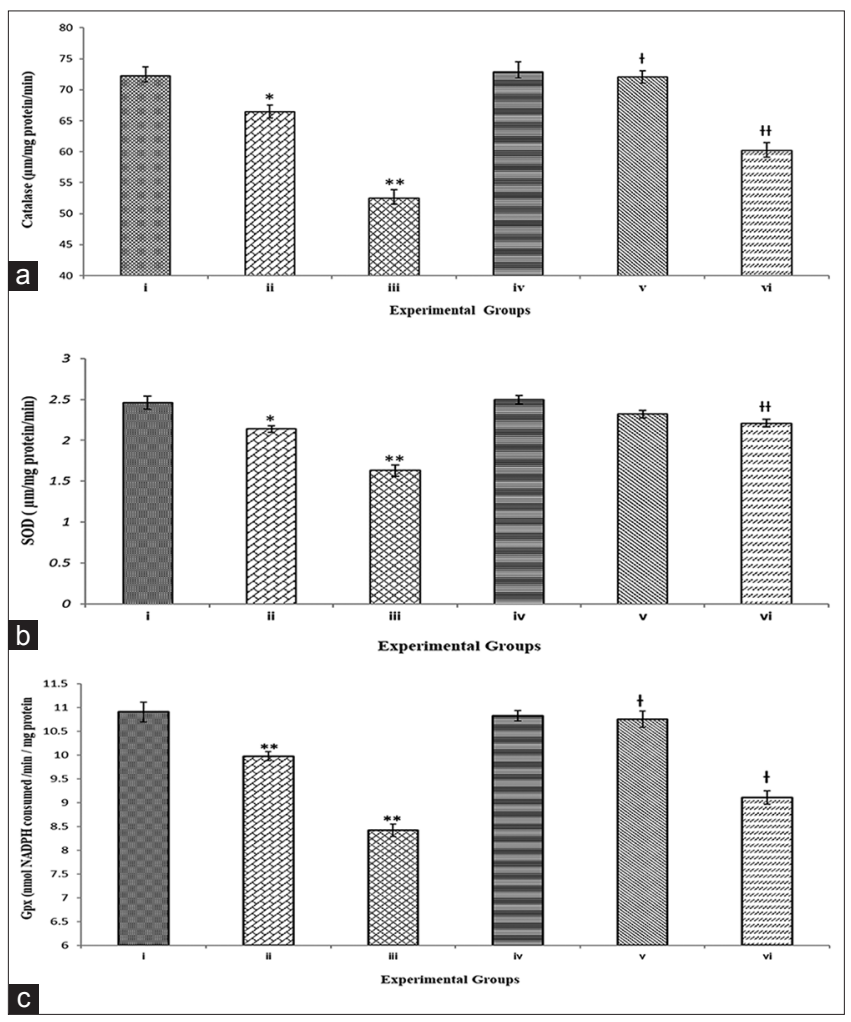

Fig. 2: Antioxidant enzymes level in the liver of control and treated mice. (a) Catalase, (b) superoxide dismutase, (c) glutathione peroxidase. ${ }^{*} \mathbf{p}<0.05$ in comparison to control, ${ }^{* *} \mathbf{p}<0.01$ in comparison to control, ${ }^{\mathrm{t}} \mathrm{p}<0.05$ in comparison to low-dose and/or high-dose group, " $\mathrm{p}<0.01$ in comparison to highdose and/or low-dose group
Liver is the active site of metabolism, organ of vital significance, and very sensitive to intoxication [8]. In this study, fluoride-induced liver toxicity was assayed by the estimation of SOD, CAT, and GPx levels and by histopathological examination. The results suggest that NaF elicited toxicity as evidenced by a decrease in the activity of antioxidant enzymes, namely, SOD, CAT, and GPx in the liver (Fig. 2 a-c). Shanthakumari et al. also reported a decrease in the activities of SOD, CAT, and GPx in the liver of fluoridetreated rats [24]. Decrease in the enzyme activities has also been reported in brain and gastrocnemius muscle of mice after NaF treatment [25]. Patel and Chinoy found that fluoride impaired the functioning of the SOD and CAT enzymes in the ovary of mice [26]. Antioxidant enzymes play an important role in the conversion of active oxygen molecules into non-toxic compounds. It is apparent from the literature that $\mathrm{NaF}$ generates reactive oxygen species (ROS) by decreasing the activities of antioxidant enzymes (CAT, SOD, and GPx), thereby causing oxidative stress [27-30] which causes lesions in the liver of mice and rats [31]. SOD promotes the reduction of superoxide into hydrogen peroxide, which has to be eliminated by GPx and/or CAT [32]. CAT, SOD, and GPx are able to scavenge free radicals from the liver. Free radicals disrupt the oxidant-antioxidant balance in the cells, which causes oxidative stress and damage to deoxyribonucleic acids, proteins, and lipids [33,34]. An in vitro study conducted on BV-2 microglial cells found enhanced reactive oxygen species which result into oxidative stress after exposure to $\mathrm{NaF}$ [35].

Decreased activities of SOD, CAT, and GPx in the liver were reported earlier in rats, pig, and mice receiving various concentrations of $\mathrm{NaF}$

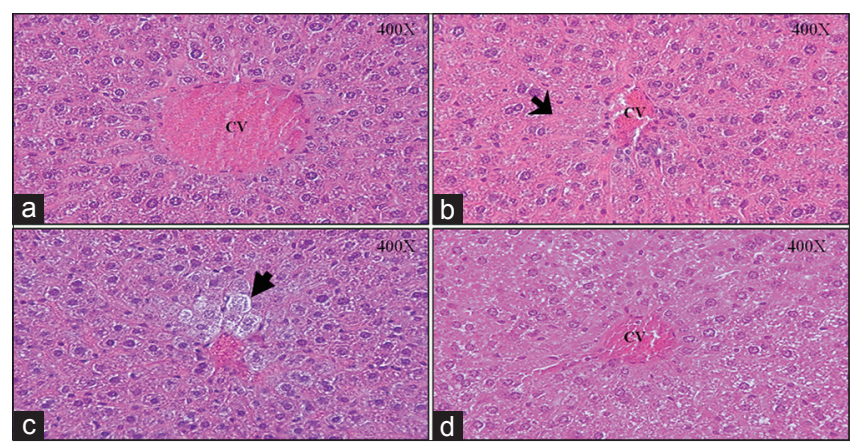

Fig. 3: Liver histology of control and treated mice. (a) Normal histology showing central vein (CV) of control mice, (b) Distortion of CV and appearance of hypertrophy ( 3 ), (c) ballooned hepatocytes ( $\bullet)$, (d) restoration of normal features by Ocimum sanctum Linn

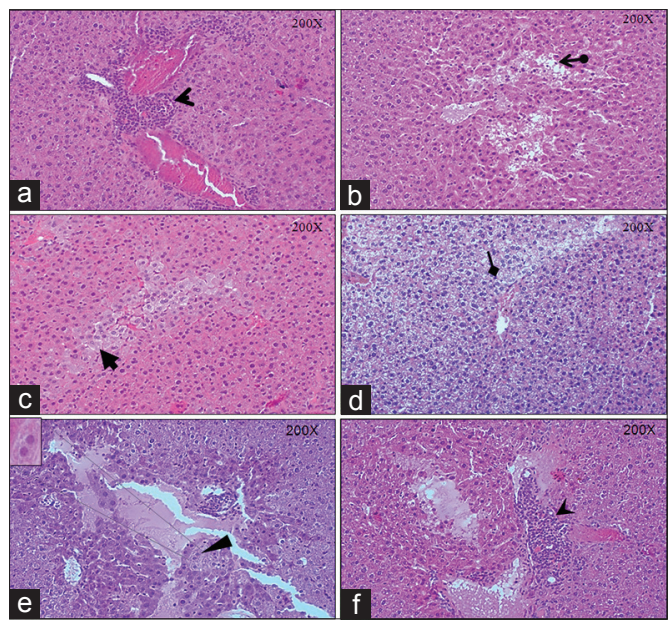

Fig. 4: Liver histology of control and treated mice (a) monocytes Infiltration within portal tetrad ( () ), (b) cell degeneration $(\leftarrow)$,

(c) ballooned hepatocytes $(\leftarrow),(d)$ necrosis $(\rightarrow),(e)$ binucleated hepatocytes ( $)$, (f) infiltration of monocytes $(\mathcal{L})$ 
Table 1: Histopathological grading of liver after exposure to fluoride and $O$. sanctum Linn. in mice

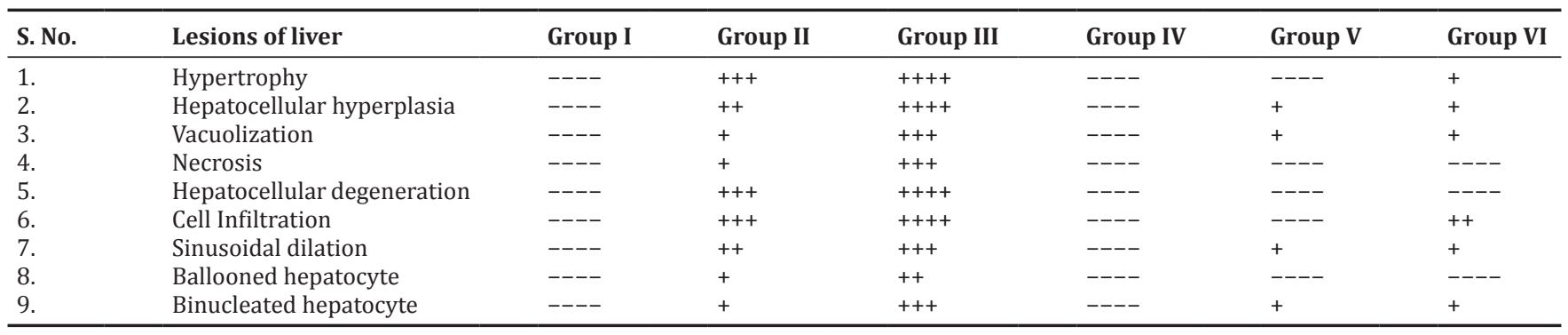

++++: Severe, +++: Moderate, ++: Mild, +: Few/Minimum, ----: Absent/Nil. O. sanctum: Ocimum sanctum

in drinking water [36-38]. The activity of SOD, CAT, and GPx is reduced more noticeable in the liver as compared to other organs, suggesting liver to be more prone to the toxic effects of fluoride [39].

Reduced activity of antioxidant enzymes is associated with the generation of free radicals in cells which cause anomalies in the liver. High dose of $\mathrm{NaF}$ in the present study elicited hepatic abnormalities such as ballooning, hypertrophy, hepatocellular necrosis, infiltration of mononuclear cells, deformed central vein, sinusoidal dilation, and binucleated cells. Bouaziz et al. showed ballooning, necrosis, and mononuclear cells infiltration in the liver of mice that were treated with $\mathrm{NaF}$ [40]. Degenerative and necrotic changes in the liver and kidney of rabbits have also been reported with high concentration of $\mathrm{NaF}[8,41]$. Chinoy et al. observed pyknosis of nuclei, zonal necrosis, and disintegration of the organization of hepatic cords in fluorideadministered rats [42]. Vinyl fluoride is reported to cause hepatic tissue aberrations such as sinusoidal dilation and adenoma in rats [43].

The mice treated with the ethanolic leaf extract of $O$. sanctum Linn. at the dose of $250 \mathrm{mg} / \mathrm{kg}$ body weight showed a significant increase in levels of SOD, CAT, and GPx and restored normal histology, thereby indicating significant hepatoprotective activity (Figs. 2a-c and 3d). Lahon and Das [44] and Chattopadhyay et al. [45] also reported that alcoholic leaf extract of 0 . sanctum Linn. shows significant hepatoprotective activity against paracetamol-induced liver damage in rats. This may be attributed to the presence of components such as eugenol, flavonoid, linoleic acid, and ursolic acid in the leaves of 0 . sanctum Linn. [46,47]. These phytochemicals have free radical scavenging property. Hydrogen peroxide-induced DNA breaks, ROS, and formation of 8-OH-dG are inhibited by ursolic acid [16]. O. sanctum Linn. has also been reported to have defending role against the imbalance of xenobiotic-metabolizing enzymes and oxidative stress $[48,49]$. This extract reduces the oxidation of lipid and proteins and modulates xenobiotic metabolization which promotes antioxidant defenses [50].

\section{CONCLUSION}

It may be concluded that fluoride exposure reduces antioxidative enzyme activities which leads to oxidative stress and tissue injury. Furthermore, O. sanctum Linn. elicits hepatoprotective potential and reduces harmful effects induced by fluoride treatment.

\section{ACKNOWLEDGMENT}

The financial support by Council of Scientific and Industrial Research (CSIR), New Delhi, India, and the facilities provided by the Department of Zoology, Centre for Advanced Studies, University of Rajasthan are thankfully acknowledged.

\section{AUTHOR'S CONTRIBUTION}

Bhagwendra Prakash carried out the experiment. Bhagwendra Prakash and Inderpal Soni wrote the manuscript with support from PJ John. Suresh Kumar Sabal and Rajbala Verma help in the computational framework and analysis of the data.

\section{CONFLICTS OF INTEREST STATEMENT}

The authors declare that there are no conflicts of interest.

\section{REFERENCES}

1. WHO. Environmental health criteria 36. Fluor Fluorid 1984;1:25-36.

2. Li Y, Dunipace AJ, Stookey GK. Genotoxic effects of fluoride: A controversial issue. Mutant Res 1988;195:127-36.

3. Medical Research Council Working Group. Water Fluoridation and Health Report. London: MRC; 2002.

4. WHO. Guidelines for Drinking-Water Quality: Fourth Edition Incorporating the First Addendum, 2017.

5. Das S, Maiti R, Ghosh D. Management of fluoride-induced testicular disorders by calcium and Vitamin-E co-administration in the albino rat. Reprod Toxicol 2006;22:606-12.

6. Wang YN, Xiao QX, Liu JL, Dallner G, Guan ZZ. Effect of longterm fluoride exposure on lipid composition in rat liver. Toxicology 2000;146:161-9.

7. Djouadi A, Derouiche S. Study of fluoride-induced hematological alterations and liver oxidative stress in rats. World J Pharm Pharm Sci 2017;6:211-21

8. Shashi A, Thapar SP. Histopathology of fluoride-induced hepatotoxicity in rabbits. Fluoride 2000;34:34-42.

9. Kapoor V, Prasad T, Bhatia KC. Effect of dietary fluorine on histopathological changes in calves. Fluoride 1993;26:105-10.

10. Mamczar E, Machoy Z, Tarnawski R, Birkner E, Mamczar A. Influence of long-term sodium fluoride administration on selected parameters of rat blood serum and liver function. Fluoride 1997;30:157-64.

11. Kolodziejczyk L, Put A, Grzela P. Liver morphology and histochemistry in rats resulting from ingestion of Sodium selenite and sodium fluoride. Fluoride 2000;33:6-16.

12. Vats V, Yadav SP, Grover JK. Ethanolic extract of Ocimum sanctum leaves partially attenuates streptozotocin-induced alterations in glycogen content and carbohydrate metabolism in rats. J Ethnopharmacol 2004;90:155-60.

13. Hannan JM, Marenah L, Ali L, Rokeya B, Flatt PR, Abdel-Wahab YH, et al. Ocimum sanctum leaf extracts stimulate insulin secretion from perfused pancreas, isolated islets and clonal pancreatic beta-cells. J Endocrinol 2006;189:127-36.

14. Gupta S, Mediratta PK, Singh S, Sharma KK, Shukla R. Antidiabetic, antihypercholesterolaemic and antioxidant effect of Ocimum sanctum (Linn) seed oil. Indian J Exp Biol 2006;44:300-4

15. Magesh V, Lee JC, Ahn KS, Lee HJ, Lee HJ, Lee EO, et al. Ocimum sanctum induces apoptosis in A549 lung cancer cells and suppresses the in vivo growth of lewis lung carcinoma cells. Phytother Res 2009;23:1385-91.

16. Batra A, Sastry VG. Extraction of ursolic acid from Ocimum sanctum and synthesis of its derivatives: Comparative evaluation of antioxidant activities. J Pharm Sci Res 2014;5:5059-65.

17. Pemminati S, Swati B, Shreyasi C, Chandrasekhar R, Gopalakrishna HN, Pai MR. Anxiolytic activity of ethanolic extract of leaves of Ocimum sanctum in rats. Drug Invent Today 2010;2:115-8.

18. Basu A, Mitra E, Mukherjee D, Ghosh AK, Firdaus SB, Ghosh D, et al. Aqueous tulsi leaf (Ocimum sanctum L.) extract protects against piroxicam-induced gastric ulceration in rats: Involvement of antioxidant mechanisms. Int J Pharm Pharm Sci 2013;5:438-47.

19. Sridevi M, Bright J, Yamini K. Anti-cancer effect of Ocimum sanctum ethanolic extract in non-small cell lung carcinoma cell line. Int J Pharm Pharm Sci 2016;8:242-6.

20. Aebi H. Catalase in vitro. Methods Enzymol 1984;105:121-6. 
21. Marklund S, Marklund G. Involvement of the superoxide anion radical in the autoxidation of pyrogallol and a convenient assay for superoxide dismutase. Eur J Biochem 1974;47:469-74.21.

22. Paglia DE, Valentine WN. Studies on the quantitative and qualitative characterization of erythrocyte glutathione peroxidase. J Lab Clin Med 1967;70:158-69.

23. Lowry OH, Rosebrough NJ, Farr Al, Randall RJ. Protein measurement with the folin phenol reagent. J Biol Chem 1951;193:265-75.

24. Shanthakumari D, Srinivasalu S, Subramanian S. Effect of fluoride intoxication on lipidperoxidation and antioxidant status in experimental rats. Toxicology 2004;204:219-28

25. Vani ML, Reddy KP. Effect of fluoride accumulation on some enzyme of brain and gastrocnemius muscle of mice. Fluoride 2000;33:17-26.

26. Patel D, Chinoy NJ. Influence of fluoride on biological free radical reactions in ovary of mice and its reversal. Fluoride 1998;31:S27.

27. Krechniak J, Inkielewicza I. Correlations between fluoride concentrations and free radical parameters in soft tissues of rats. Fluoride 2005;38:293-6.

28. Chouhan S, Flora SJ. Effects of fluoride on the tissue oxidative stress and apoptosis in rats: Biochemical assays supported by IR spectroscopy data. Toxicology 2008;254:61-7.

29. Ailani V, Gupta RC, Gupta SK, Gupta K. Oxidative stress in cases of chronic fluoride intoxication. Indian J Clin Biochem 2009;24:426-9.

30. Hassan HA, Abdel-Aziz AF. Evaluation of free radical-scavenging and anti-oxidant properties of blackberry against fluoride toxicity in rats. Food Chem Toxicol 2010;48:1999-2004.

31. Chattopadhyay A, Podder S, Agarwal S, Bhattacharya S. Fluorideinduced histopathology and synthesis of stress protein in liver and kidney of mice. Arch Toxicol 2011;85:327-35.

32. Weydert CJ, Cullen JJ. Measurement of superoxide dismutase, catalase and glutathione peroxidase in cultured cells and tissue. Nat Protoc 2010;5:51-66.

33. Bartsch H, Nair J. Ultrasensitive and specific detection method for exocyclic DNA adducts: Markers for lipid peroxidation and oxidative stress. Toxicology 2000;153:105-14.

34. Sharma A, Chinoy NJ. Role of free radicals in fluoride-induced toxicity in liver and kidney of mice and its reversal. Fluoride 1998;31:26-30.

35. Shuhua X, Ziyou L, Ling Y, Fei W, Sun G. A role of fluoride on free radical generation and oxidative stress in BV-2 microglia cells. Mediators Inflamm 2012;2012:102954.

36. Guo X, Sun G, Sun Y. Oxidative stress from fluoride induced hepatotoxicity in rats. Fluoride 2003;36:25-9.
37. Zhan XA, Min W, Rong XZ, Fen LW, Li JX. Effects of fluoride on hepatic antioxidant system and transcription of $\mathrm{Cu} / \mathrm{Zn}$ SOD gene in young pigs. J Trace Elem Med Biol 2006;20:83-7.

38. J M, Sinha S, Ghosh M, Mukherjee A. Evaluation of multi-endpoint assay to detect genotoxicity and oxidative stress in mice exposed to sodium fluoride. Mutat Res 2013;751:59-65.

39. Flora SJ, Mittal M, Pachauri V, Dwivedi N. A possible mechanism for combined arsenic and fluoride induced cellular and DNA damage in mice. Metallomics 2012;4:78-90.

40. Bouaziz H, Ketata S, Jammoussi K, Boudawara T, Ayedi F, Ellouze F, et al. Effects of sodium fluoride on hepatic toxicity in adult mice and their suckling pups. Pestic Biochem Physiol 2006;86:124-30.

41. Shashi A, Singh JP, Thapar SP. Toxic effects of fluoride on rabbit kidney. Fluoride 2002;35:38-50.

42. Chinoy NJ, Joseph R, Sequeira E, Narayana MV. Effects of sodium fluoride on the muscle and liver of albino rats. Indian J Environ Biol 1991;1:129-34.

43. Bogdanffy MS, Makovec GT, Frame SR. Inhalation oncogenicity bioassay in rats and mice with vinyl fluoride. Fundam Appl Toxicol 1995;26:223-38

44. Lahon K, Das S. Hepatoprotective activity of Ocimum sanctum alcoholic leaf extract against paracetamol-induced liver damage in Albino rats. Pharmacog Res 2011;3:13-8.

45. Chattopadhyay RR, Sarkar SK, Ganguly S, Medda C, Basu TK. Hepatoprotective activity of Ocimum sanctum leaf extracts against paracetamol-induced hepatic damage in rats. Indian $\mathrm{J}$ Pharmacol 1992;24:163-5.

46. Liu J. Pharmacology of oleanolic acid and ursolic acid. J Ethnopharmacol 1995;49:57-68.

47. Sen P. Therapeutic potentials of Tulsi: From experience to facts. Drugs News Views 1993;1:15-21.

48. Kath RK, Gupta RK. Antioxidant activity of hydroalcoholic leaf extract of Ocimum sanctum in animal models of peptic ulcer. Indian J Physiol Pharmacol 2006;50:391-6.

49. Siddique Y, Ara G, Beg T, Afzal M. Anti-genotoxic effect of Ocimum sanctum $\mathrm{L}$. extract against cyproterone acetate induced genotoxic damage in cultured mammalian cells. Acta Biol Hung 2007;58:397-409.

50. Manikandan P, Murugan RS, Abbas H, Abraham SK, Nagini S. Ocimum sanctum Linn. (holy basil) ethanolic leaf extract protects against 7,12-dimethylbenz[a] anthracene-induced genotoxicity, oxidative stress, and imbalance in xenobiotic-metabolizing enzymes. J Med Food 2007; 10:495-502. 